\title{
ANALISIS KINERJA KEUANGAN DAN HARGA SAHAM PERBANKAN DI BURSA EFEK INDONESIA (BEI)
}

\author{
Wijayanti \\ Fakultas Ekonomi Universitas Brawijaya
}

\begin{abstract}
This research was aimed at searching the anwer for question whether financial achievement of firm really affected the price of its stock or the speculative activites were the main sources for stock price fluctuation. Financial performance was shown by some fundamental indicators such as CAR, ROA, NIM, NPL, LDR, EPS, and $P E R$, while speculation often look over the historical pattern of stock prices in the past which indicated by P1 and P2. Regression was used as the tools for analyzing the problem. Data were collected from all banks listed in BEJ in 2005. The research found that overall, all variables had significant impact on stock prices, but not all individual variable had the same role. Variables: ROA, NIM, EPS, PER, and PI were individually had significant impact on the stock price while CAR, NPL, LDR and $P 2$ did not. Thus, author concluded that beside financial indicators could influence people to buy and sell their stock, the stock price was also still significantly affected by the action of speculants.
\end{abstract}

Keywords: financial achievement, speculation, banks, stock price.

\section{A. LATAR BELAKANG}

Analisa terhadap penilaian harga saham merupakan langkah mendasar yang harus dilakukan oleh investor sebelum melakukan investasi, supaya investor tidak terjebak pada kondisi yang merugikan. Dimana harga saham di bursa efek ditentukan menurut hukum permintaan dan penawaran (kekuatan tawar menawar). Semakin banyak orang yang ingin membeli saham, maka harga saham akan cenderung bergerak naik, sebaliknya semakin banyak orang-orang yang akan menjual saham tersebut, maka harga saham cenderung akan bergerak turun.

Pergerakan harga saham dalam kenyataannya akan dipengaruhi oleh faktor fundamental dan faktor teknikal. Dalam jangka pendek, maka faktor-faktor yang bersifat teknikal biasanya akan mempengaruhi fluktuasi harga saham. Sementara dalam jangka panjang maka biasanya faktorfaktor fundamental yang sesungguhnya akan menentukan harga saham.

Berdasarkan uraian singkat di atas, maka penelitian ini berusaha untuk mendapat jawaban apakah, rasio-rasio kinerja keuangan yang terdiri dari CAR, ROA, NIM, NPL, LDR, EPS, PER, serta faktor teknikal yaitu Harga Saham Masa Lalu satu tahun dan dua tahun sebelumnya memiliki pengaruh yang signifikan terhadap harga saham perbankan yang listing di Bursa Efek Indonesia (BEI) pada tahun 2005. 


\section{Journal of Indonesian Applied Economics}

\section{Vol. 4 No. 1 Mei 2010, 71-80}

\section{B. KAJIAN TEORITIS}

Analisa terhadap penilaian harga saham merupakan langkah mendasar yang harus dilakukan oleh investor sebelum melakukan investasi, supaya investor tidak terjebak pada kondisi yang merugikan. Harga saham berubah (berfluktuasi) sesuai dengan kekuatan permintaan (demand) dan penawaran (supply). Salah satu faktor yang mempengaruhi pembelian saham (permintaan) didasarkan pada pertimbangan fundamental yaitu kinerja keuangan perusahaan.

Dengan kinerja keuangan yang baik, maka perusahaan tersebut mampu menghasilkan keuntungan yang tinggi dan sekaligus dapat menyisihkan bagian keuntungan itu sebagai deviden yang tinggi pula, sehingga hal tersebut akan mempengaruhi permintaan akan saham. Dalam mengevaluasi kinerja keuangan suatu perusahaan, diperlukan ukuran tertentu. Ukuran yang sering digunakan adalah rasio yang berhubungan dengan data keuangan. Dimana dalam penelitian ini rasio kinerja keuangan yang digunakan adalah CAR, ROA, NIM, NPL, LDR, EPS, dan PER.

Selain melakukan analisis fundamental, investor juga melakukan analisis teknikal yang digunakan untuk penilaian terhadap suatu saham sebagai dasar investor untuk melakukan penjualan saham (penawaran). Pihak yang dianggap menggunakan pendekatan teknikal adalah para spekulan yang hanya berpatokan jangka pendek dengan tujuan untuk mendapatkan capital gain. Dimana faktor teknikal yang digunakan dalam penelitian ini adalah harga saham masa lalu satu tahun sebelumnya (P1) dan dua tahun sebelumnya (P2).

Harga saham masa lalu mempengaruhi harga saham sekarang yang mempunyai pola tertentu dan berulang sehingga berpengaruh secara psikologis terhadap investor dalam melakukan transaksi perdagangan. Banyak analis teknikal percaya bahwa gerakan harga saham akan mengikuti pola triple top (Husnan, 2003).

Analis yang percaya pada pola triple tops ini berpendapat, bahwa setelah melalui tiga puncak harga maka saham tersebut akan jatuh harganya (Husnan, 2003). Keadaan ini ditunjukkan oleh gambar berikut:

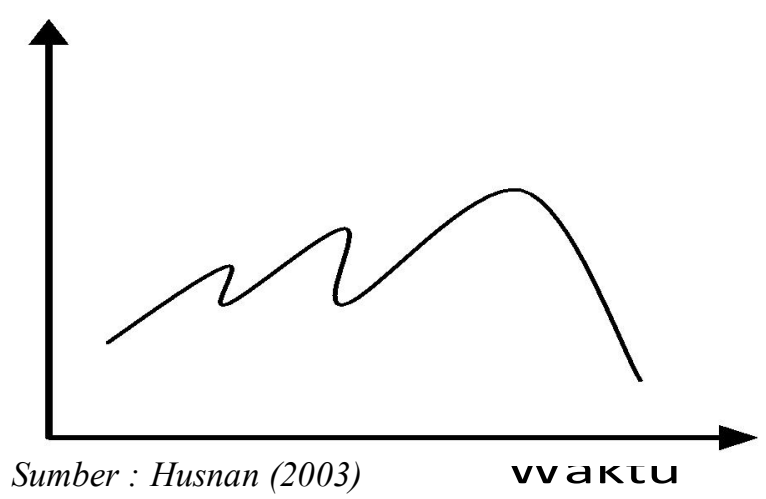

\section{Gambar 1. Pola Triple Tops}

Jadi apabila seorang analis menemukan bahwa suatu saham telah menempuh tiga kali harga tinggi (ditunjukan oleh titik C) maka saham tersebut harus dijual (short selling).

Oleh karena itu dalam penelitian ini akan menggunakan faktor-faktor yang mempengaruhi pembelian saham (permintaan), yaitu kinerja keuangan dan yang mempengaruhi penjualan saham (penawaran), yaitu harga saham masa lalu. Dari kekuatan permintaan dan penawaran itu akan terbentuk harga saham di pasar modal. 


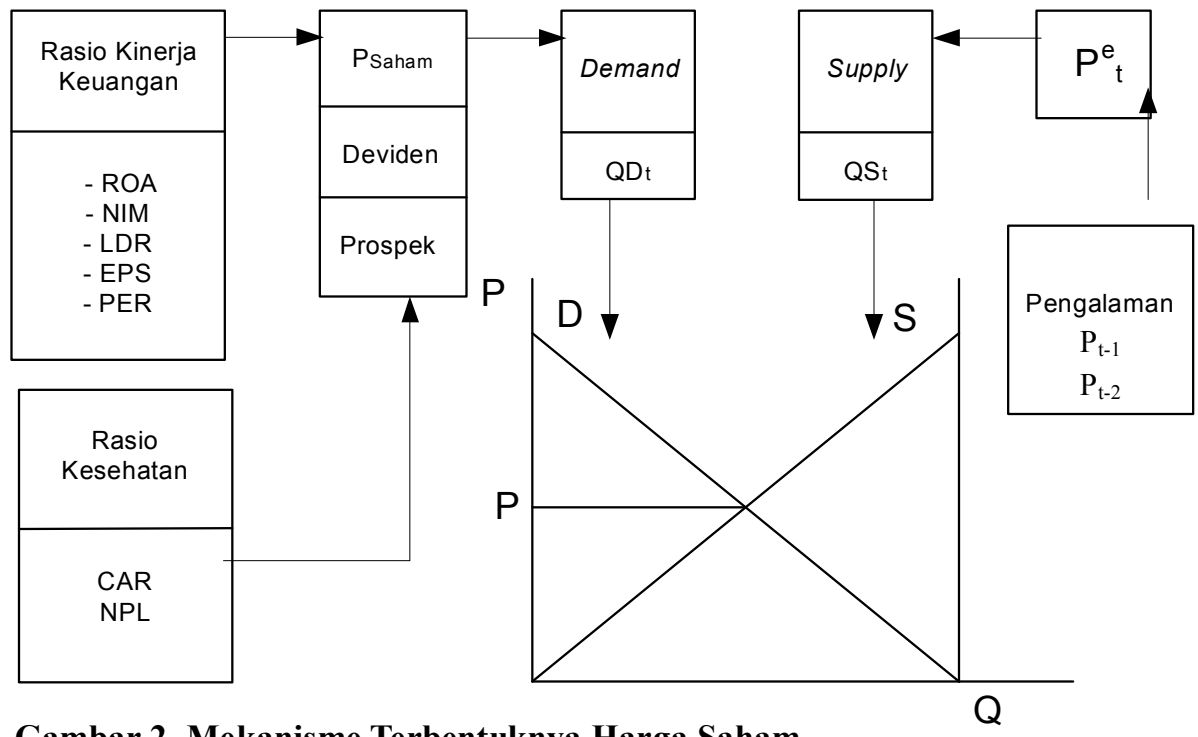

Gambar 2. Mekanisme Terbentuknya Harga Saham

Fungsi : $\mathrm{QD}_{\mathrm{t}}=\mathrm{f}\left(\mathrm{P}_{\mathrm{t}}\right.$ rasio kinerja, rasio kesehatan $)$

$\mathrm{QS}_{\mathrm{t}}=\mathrm{f}\left(\mathrm{P}_{\mathrm{t}-1, \mathrm{P}_{\mathrm{t}-2}}\right)$

$\mathrm{QD}_{\mathrm{t}}=\mathrm{QS}_{\mathrm{t}}$

$\mathrm{f}\left(\mathrm{P}_{\mathrm{t}}\right.$ rasio kinerja, rasio kesehatan $)=\mathrm{f}\left(\mathrm{P}_{\mathrm{t}-1,1} \mathrm{P}_{\mathrm{t}-2}\right)$

$\mathrm{P}_{\mathrm{t}}=\mathrm{f}\left(\mathrm{P}_{\mathrm{t}-1}, \mathrm{P}_{\mathrm{t}-2=}\right.$, rasio-rasio kinerja keuangan, rasio-rasio kesehatan $)$

\section{Hipotesis}

Hipotesa merupakan dugaan atau jawaban sementara dari masalah yang dibahas berlandaskan teori dan sumber-sumber lain yang relevan. Hipotesa dari penelitian ini adalah diduga bahwa rasio-rasio kinerja keuangan yang terdiri dari:

- CAR memiliki pengaruh positif terhadap harga saham perbankan.

- ROA memiliki pengaruh positif terhadap harga saham perbankan.

- NIM memiliki pengaruh positif terhadap harga saham perbankan.

- NPL memiliki pengaruh negatif terhadap harga saham perbankan.

- LDR memiliki pengaruh positif terhadap harga saham perbankan.

- EPS memiliki pengaruh positif terhadap harga saham perbankan.

- PER memiliki pengaruh positif terhadap harga saham perbankan.

Serta faktor teknikal yaitu:

- Harga saham masa lalu satu tahun sebelumnya (P1) memiliki pengaruh positif terhadap harga saham perbankan.

- Harga saham masa lalu dua tahun sebelumnya (P2) memiliki pengaruh positif terhadap harga saham perbankan.

\section{METODE PENELITIAN DAN ANALISIS DATA}

\section{Populasi dan Sampel}

Populasi dari penelitian ini adalah kelompok perusahaan perbankan yang terdaftar (listing) di BEJ.. Penentuan sampel dalam penelitian ini menggunakan teknik purposive sampling yaitu sebuah sampel non probability yang menyesuaikan diri dengan kriteria tertentu. Alasan penggunaan metode purposive sampling adalah supaya sampel yang dipilih memenuhi kriteria sesuai dengan tujuan 


\section{Journal of Indonesian Applied Economics}

penelitian yaitu mengamati kinerja keuangan bank dan harga saham masa lalu yang dikaitkan dengan perubahan harga saham. Adapun sampel yang dipilih berdasarkan pertimbanganpertimbangan tertentu, yaitu:

1. Perusahaan perbankan yang terdaftar di Bursa Efek Jakarta (BEJ) pada tahun 2005.

2. Perusahaan perbankan yang mempublikasikan laporan keuangan selama tahun penelitian.

\section{Jenis Data dan Sumber Data}

Data yang digunakan dalam penelitian ini adalah data sekunder, dan jenis data dalam penelitian ini adalah data cross section. Data-data tersebut berupa rasio keuangan sebagai ukuran kinerja keuangan dan harga saham masa lalu. Sedangkan data-data dalam penelitian ini diperoleh dari Indonesia Capital Market Directory (ICMD) tahun 2005, Annual Report Perusahaan perbankan, Info Bank, dan JSX monthly statistic.

\section{Variabel Penelitian dan Definisi Operasional}

Variabel yang diteliti dalam penelitian ini dapat di kelompokkan sebagai berikut:

1. Variabel terikat (Y) atau dependent variabel, yaitu variabel yang nilainya bergantung dari nilai variabel lainnya. Sebagai variabel terikat dalam penelitian ini adalah harga saham. Harga saham yang dimaksud adalah Average Close Price (ACP) yaitu rata-rata harga saham penutupan bulanan dalam satu tahun selama 5 tahun.

2. Variabel bebas $(\mathrm{X})$ atau independent variabel, yaitu variabel yang nilainya tidak bergantung variabel lain. Sebagai variabel bebas dalam penelitian ini adalah: CAR $\left(\mathrm{X}_{1}\right)$, ROA $\left(\mathrm{X}_{2}\right)$, NIM $\left(X_{3}\right)$, NPL $\left(X_{4}\right)$, LDR $\left(X_{5}\right)$, EPS $\left(X_{6}\right)$, PER $\left(X_{7}\right)$, Harga saham masa lalu satu tahun sebelumnya $\left(\mathrm{X}_{8}\right)$, dan Harga saham masa lalu dua tahun sebelumnya $\left(\mathrm{X}_{9}\right)$.

\section{Spesifikasi Model}

Di dalam penelitian ini, untuk mengetahui bagaimana pengaruh suatu variabel bebas terhadap variabel terikatnya digunakan model analisa regresi berganda, dengan model persamaan sebagai berikut:

$Y=\alpha+\beta_{1} X_{1}+\beta_{2} X_{2}+\beta_{3} X_{3}+\beta_{4} X_{4}+\beta_{5} X_{5}+\beta_{6} X_{6}+\beta_{7} X_{7}+\beta_{8} X_{8}+\beta_{9} X_{9}+e$

Dimana:

$\mathrm{Y}=$ Rata-rata harga saham penutupan bulanan

$\alpha=$ Konstanta

$\beta_{1}, \beta_{2}, \beta_{3}, \ldots, \beta_{n}=$ Koefisien regresi

$\mathrm{X}_{1}=$ Capital Adequacy Ratio (CAR)

$\mathrm{X}_{2}=$ Return on Average Assets (ROA)

$\mathrm{X}_{3}=$ Non Performing Loans (NPL)

$\mathrm{X}_{4}=$ Loan to Deposit Ratio (LDR)

$\mathrm{X}_{5}=$ Net Interest Margin (NIM)

$\mathrm{X}_{6}=$ Earning Per Share (EPS)

$\mathrm{X}_{7}=$ Price earning Ratio (PER)

$\mathrm{X}_{8}=$ Harga saham masa lalu satu tahun sebelumnya

$\mathrm{X}_{9}=$ Harga saham masa lalu dua tahun sebelumnya

$\mathrm{e}=$ Kesalahan pengganggu

\section{Uji Statistik}

Uji statistik digunakan untuk mengetahui apakah variabel independent yang terdiri dari rasio kinerja keuangan yaitu: Capital Adequacy Ratio (CAR), Return on Average Assets (ROA), Return on Average equity (ROE), Non Performing Loans (NPL), Loan to Deposit Ratio (LDR), Net Interest 
Margin (NIM) Earning Per Share (EPS), Price earning Ratio (PER) dan harga saham masa lalu mempunyai pengaruh yang signifikan terhadap harga saham. Bentuk pengujian statistik yaitu:

\section{a. Uji t (Partial Individual Test)}

Uji t digunakan untuk mengetahui apakah variabel independen secara partial mempunyai pengaruh signifikan terhadap variabel dependen. Pengujian dapat dilakukan dengan membandingkan probabilitas value dengan $\alpha(\alpha=10 \%)$ sebagai berikut:

- Jika probabilitas value $>\alpha$, artinya variabel independen secara simultan tidak berpengaruh signifikan terhadap variabel dependen.

- Jika probabilitas value $<$, artinya variabel independen secara simultan berpengaruh signifikan terhadap variabel dependen.

\section{b. Uji F (Overall significance Test)}

Pengujian ini dilakukan untuk mengetahui apakah seluruh variabel independen berpengaruh secara simultan atau serentak terhadap variabel dependen. Pengujian dapat dilakukan dengan membandingkan probabilitas value dengan $(=10 \%)$ sebagai berikut:

- Jika probabilitas value>, artinya variabel independen secara simultan tidak berpengaruh signifikan terhadap variabel dependen.

- ika probabilitas value $<$, artinya variabel independen secara simultan berpengaruh signifikan terhadap variabel dependen.

\section{HASIL ANALISIS DATA}

Untuk mengetahui seberapa besar pengaruh variabel bebas terhadap variabel terikat, maka digunakan model analisis regresi berganda yang hasilnya ditunjukkan pada tabel 1. berikut:

Tabel 1. Hasil Estimasi Persamaan Regresi

\begin{tabular}{|c|c|c|c|}
\hline \multicolumn{4}{|c|}{ Variabel Dependen : PSHM } \\
\hline \multicolumn{4}{|c|}{ Sampel: 119} \\
\hline Variabel & Koefisien & t-Statistik & Probabilitas \\
\hline $\mathrm{C}$ & 776.4549 & 0.993191 & 0.3466 \\
\hline CAR & 5.257032 & 0.282169 & 0.7842 \\
\hline ROA & -240.4925 & -3.451353 & 0.0073 \\
\hline NIM & -210.6037 & -2.194634 & 0.0558 \\
\hline NPL & -17.51830 & -0.730484 & 0.4837 \\
\hline LDR & -0.146628 & -0.030255 & 0.9765 \\
\hline EPS & 7.638149 & 5.440691 & 0.0004 \\
\hline PER & 47.27966 & 3.751803 & 0.0045 \\
\hline $\mathrm{P} 1$ & 0.551329 & 2.646983 & 0.0266 \\
\hline $\mathrm{P} 2$ & 0.066050 & 0.636672 & 0.5402 \\
\hline \multicolumn{3}{|c|}{ R-Squared } & 0.978608 \\
\hline \multicolumn{3}{|l|}{ F-Statistik } & 45.74558 \\
\hline \multicolumn{3}{|c|}{ Prob(F-Statistik) } & 0.000002 \\
\hline
\end{tabular}

Sumber:data diolah 


\section{Journal of Indonesian Applied Economics}

Model di atas, diestimasi dengan menggunakan OLS dan untuk itu perlu dipenuhi beberapa asumsi yang berkaitan dengan metode estmasi. Di mana hasil uji asumsi heteroskedastisitas yang menggunakan uji Park dapat disimpulkan bahwa hipotesis yang menyatakan terdapat masalah heteroskedastisitas dalam model empiris diterima. Hal ini dikarenakan terdapat variabel independen yang signifikan secara statistik pada tingkat signifikansi $10 \%$. Karena model regresi linear tersebut tidak lolos dari masalah heteroskedastisitas, maka tindakan perbaikan dilakukan dengan melakukan koreksi t-Statistik. Tindakan perbaikan ini dilakukan supaya hasil estimasi OLS menjadi efisien, sehingga pengujian hipotesis tidak diragukan lagi nilainya.

Adapun hasil estimasi OLS dari persamaan regresi yang telah dikoreksi t-Statistiknya dapat dilihat pada tabel dibawah ini:

\section{Tabel 2. Hasil Estimasi Persamaan Regresi}

Variabel Dependen : PSHM

Sampel : 119

\begin{tabular}{cr|r|r}
\hline Variabel & Koefisien & t-Statistik & Probabilitas \\
C & 776.4549 & 0.783937 & 0.4532 \\
CAR & 5.257032 & 0.226298 & 0.8260 \\
\hline ROA & -240.4925 & -4.456079 & 0.0016 \\
\hline NIM & -210.6037 & -1.876904 & 0.0933 \\
\hline NPL & -17.51830 & -0.802868 & 0.4427 \\
\hline LDR & -0.146628 & -0.026785 & 0.9792 \\
\hline EPS & 7.638149 & 7.121170 & 0.0001 \\
PER & 47.27966 & 3.320127 & 0.0089 \\
P1 & 0.551329 & 2.678214 & 0.0253 \\
\hline P2 & 0.066050 & 0.770177 & 0.4609 \\
\hline R-Squared & & 0.978608 \\
\hline F-Statistik & & 45.74558 \\
\hline \multicolumn{2}{l}{ Prob(F-Statistik) } \\
\hline
\end{tabular}

Sumber:data diolah

Tampak dari hasil estimasi OLS dengan menggunakan persamaan regrsi di atas dapat diketahui bahwa seluruh variabel independen secara bersamaan memiliki pengaruh yang signifikan terhadap harga saham. Pernyataan ini dapat ditunjukkan oleh probabilitas sebesar 0.000002 (signifikan pada level $10 \%$ ). Hal ini menguatkan hipotesis bahwa perubahan CAR, ROA, NIM, NPL, LDR, EPS, PER, P1 (harga saham masa lalu satu tahun sebelumnya), P2 ( harga saham masa lalu dua tahun sebelumnya) mempunyai pengaruh signifikan secara bersama-sama terhadap harga saham.

Dapat ditambahkan pula bahwa dengan nilai F-statistik sebesar 45,746 menunjukkan bahwa secara bersama-sama variabel bebas memiliki pengaruh yang signifikan terhadap harga saham. Dari hasil regresi juga ditampilkan besaran R-Squared $\left(\mathrm{R}^{2}\right)$ sebesar 0,9786 atau $97,86 \%$. Hal ini menunjukkan bahwa variabel terikat Y mampu dijelaskan variabel independen sebesar 97,86 \%. Sedangkan 2,14\% sisanya dipengaruhi variabel lain yang tidak diteliti dalam penelitian ini.

Berdasarkan tabel tersebut probabilitas variabel CAR sebesar 0,8260 lebih besar dari 0,10 berarti Ho diterima. Probabilitas variabel ROA sebesar 0,0016 lebih kecil dari 0,10 berarti Ho ditolak. Probabilitas variabel NIM sebesar 0,0933 lebih kecil dari 0,10 berarti Ho ditolak. Probabilitas 
variabel NPL sebesar 0,4427 lebih besar dari 0,10 berarti Ho diterima. Probabilitas variabel LDR sebesar 0,9792 lebih besar dari 0,10 berarti Ho diterima. Probabilitas variabel EPS sebesar 0,0001 lebih kecil dari 0,10 berarti Ho ditolak. Probabilitas variabel PER sebesar 0,0001 lebih kecil dari 0,10 berarti Ho ditolak. Probabilitas variabel P1 sebesar 0,0253 lebih kecil dari 0,10 berarti Ho ditolak. Probabilitas variabel P2 sebesar 0,4609 lebih besar dari 0,10 berarti Ho diterima.

Oleh karena itu dapat disimpulkan bahwa terdapat pengaruh signifikan secara parsial pada variabel ROA, NIM, EPS, PER dan Harga saham masa lalu satu tahun sebelumnya (P1) terhadap harga saham perbankan yang listing di BEJ. Tetapi variabel ROA dan NIM memiliki pengaruh yang negatif. Sedangkan CAR, NPL, LDR dan P2 menunjukkan pengaruh yang tidak signifikan.

\section{Deteksi Asumsi Klasik}

Hasil pengujian normalitas dapat dilihat bahwa nilai Jarque-Bera Normality Test Statistic $\left(\mathrm{X}_{\text {hitung }}^{2}\right)$ sebesar 1,539 sedangkan nilai $\mathrm{X}_{\text {tabel }}^{2}(9 ; 0,10)$ sebesar 14,684 . Dimana nilai $\mathrm{X}_{\text {hitung }}^{2}$ lebih kecil sehingga dapat dikatakan bahwa model empiris yang di gunakan mempunyai residual atau faktor pengganggu yang berdistribusi normal $\left(\mathrm{H}_{0}\right.$ diterima). Hasil pengujian multikolinearitas dapat dilihat pada tabel 2. di bawah ini :

\section{Tabel 3. Hasil Uji Multikolinearitas}

\begin{tabular}{l|r}
\hline Variabel Bebas & \multicolumn{1}{|c}{ Nilai V IF } \\
\hline C AR & 2,600 \\
\hline R O & 4,960 \\
\hline N IM & 2,616 \\
N L & 2,012 \\
LDR & 2,046 \\
\hline EP S & 7,435 \\
\hline PER & 7,503 \\
\hline P 1 & 2,659 \\
\hline P2 & 3,574 \\
\hline
\end{tabular}

Sumber:data diolah

Dari tabel di atas, dapat diketahui bahwa tidak terdapat masalah multikolinearitas dalam model karena nilai VIF $<10$. Uji gejala autokorelasi menggunakan uji Breusch-Godfrey Serial Correlation (LM Test). Berdasarkan hasil uji Breusch-Godfrey Serial Correlation (LM Test), maka dapat disimpulkan bahwa $\mathrm{H}_{0}$ yang menyatakan tidak terdapat masalah autokorelasi diterima. Hal ini dikarenakan nilai $X_{\text {hitung }}^{2}$ sebesar 0,960lebih kecil bila dibandingkan $X_{\text {tabel }}^{2}(9 ; 0,10)$ sebesar 14,684.

\section{HASIL DAN PEMBAHASAN}

Nilai koefisien regresi CAR sebesar 5,257, artinya CAR mempunyai pengaruh positif terhadap harga saham, tetapi berdasarkan uji $t$ variabel CAR tidak mempunyai pengaruh yang signifikan terhadap harga saham. Hal ini dapat terjadi sebagai akibat adanya ketidakmampuan dari pihak manajemen bank dalam mengelola permodalannya untuk menutup kerugian-kerugian bank yang disebabkan oleh aktiva yang beresiko. Permodalan perbankan nasional berada dalam risiko cukup tinggi akibat tekanan NPL. Tekanan NPL yang tinggi ini berpotensi meningkatkan risiko sistematik perbankan. Hal ini karena posisi rasio NPL terhadap modal perbankan masih relatif tinggi sehingga posisi rasio kecukupan modal (capital adequacy ratio/CAR) pun juga cukup sensitif terhadap 


\section{Journal of Indonesian Applied Economics Vol. 4 No. 1 Mei 2010, 71-80}

perubahan NPL. Selain itu juga disebabkan karena porsi obligasi rekap yang besar terhadap total asset perbankan. Porsi obligasi rekap yang besar terhadap total aset perbankan ini membuat kondisi bank-bank nasional praktis dalam keadaan idle atau menganggur.

Nilai koefisien regresi ROA sebesar - 40,493, artinya jika ROA mengalami peningkatan sebesar 1 persen (cateris paribus), maka akan menyebabkan penurunan nilai harga saham sebesar 240,493\%.. Hal ini terjadi karena perolehan laba besar yang tidak sustainable (berkesinambungan).

Nilai koefisien NIM sebesar-210,604 menunjukkan bahwa ketika NIM mengalami peningkatan sebesar 1 persen (cateris paribus), maka akan menyebabkan penurunan nilai harga saham sebesar 210,604\%. Hal ini terjadi karena adanya ketidakefisienan dari perbankan nasional. Jadi bisa dikatakan NIM yang tinggi bisa menandakan bank tidak efisien karena besarnya biaya operasional.

Nilai koefisien regresi NPL sebesar_17,518, artinya NPL mempunyai pengaruh negatif terhadap harga saham, tetapi berdasarkan uji t variabel NPL tidak mempunyai pengaruh yang signifikan terhadap harga saham. Hal ini terjadi karena Non Performing Loan (NPL) atau kredit bermasalah masih menjadi momok yang menakutkan bagi perbankan nasional. Meningkatnya kembali kredit bermasalah (NPL) sebagai akibat peningkatan suku bunga kredit., kenaikan BBM serta fluktuasi rupiah yang masih berpotensi liar. Peningkatan NPL juga terjadi karena penanganan kredit bermasalah oleh bank lebih mementingkan aspek legal kredit dibandingkan aspek bisnis, sehingga penanganannya kurang konkret dan substansial, dan pada akhirnya hanya memicu terjadinya penumpukan kredit bermasalah di bank-bank. Hal ini membuat sentimen buruk bagi investor, sehingga rasio NPL tidak membentuk ekspektasi investor.

Nilai koefisien regresi LDR sebesar - 0,147 , artinya LDR mempunyai pengaruh negatif terhadap harga saham, tetapi berdasarkan uji t variabel LDR tidak mempunyai pengaruh yang signifikan terhadap harga saham. Hal ini terjadi karena naiknya harga BBM menyebabkan perbankan Indonesia kesulitan menyalurkan kredit ke masyarakat. Hal ini menyebabkan bank-bank lebih suka menyimpan dana pihak ketiga (DPK) di Sertifikat Bank Indonesia (SBI). Banyaknya dana perbankan di SBI menunjukan bahwa perbankan masih sedikit memberikan kredit ke sektor riil. Dengan kata lain perbankan Indonesia kembali melupakan fungsi intermediasinya.

Nilai koefisien regresi EPS sebesar 7,638 menunjukkan bahwa ketika EPS mengalami peningkatan sebesar 1 persen (cateris paribus), maka akan menyebabkan kenaikan nilai harga saham sebesar 7,638\%. Pada umumnya manajemen perusahaan, pemegang saham biasa, dan calon pemegang saham sangat tertarik akan earning per share (EPS), karena hal ini menggambarkan jumlah rupiah yang diperoleh untuk setiap lembar saham. Para calon pemegang saham tertarik dengan EPS yang besar, karena hal ini merupakan salah satu indikator keberhasilan suatu perusahaan. Kemampuan perusahaan dalam menghasilkan keuntungan yang tinggi akan berpengaruh terhadap tingkat EPS. EPS yang tinggi menandakan bahwa perusahaan tersebut mampu memberikan tingkat kesejahteraan yang lebih baik kepada pemegang saham.

Informasi tentang EPS ini sangat penting untuk melakukan penilaian berapa perkiraan potensi pendapatan yang bakal diterima jika membeli suatu saham. Karena dengan adanya data EPS maka dapat diketahui kemampuan perusahaan dalam menghasilkan laba tiap lembar sahamnya serta dapat juga menggambarkan prospek earning perusahaan di masa yang akan datang (Tandelilin, 2004). Jadi, semakin tinggi EPS berarti semakin baik kinerja suatu perusahaan sehingga sahamnya semakin banyak diminati investor (permintaan saham perusahaan naik), yang menyebabkan semakin tinggi pula harga saham tersebut.

Nilai koefisien PER sebesar 47,279 menunjukkan bahwa ketika PER mengalami peningkatan sebesar 1 persen (cateris paribus), maka akan menyebabkan kenaikan nilai harga saham sebesar 47,279\%. Rasio PER ini mengindikasikan suatu tingkat pertumbuhan perusahaan. Semakin tinggi tingkat pertumbuhan perusahaan, maka akan semakin tinggi pula PER-nya. Nilai PER juga menunjukkan laba yang dihasilkan perusahaan. Jadi nilai PER yang positif memberikan indikasi yang sesuai dengan teori yang dikemukakan oleh Weston \& Copeland (1997), bahwa pertumbuhan laba mempunyai pengaruh positif terhadap perkembangan harga saham. Semakin tinggi tingkat pertumbuhan perusahaan maka akan semakin baik perkembangan harga sahamnya. 
Nilai koefisien harga saham masa lalu satu tahun sebelumnya (P2) sebesar 0,551 menunjukkan bahwa ketika P1 mengalami peningkatan sebesar 1 persen (cateris paribus), maka akan menyebabkan kenaikan nilai harga saham sebesar $0,551 \%$. Di mana harga saham masa lalu memegang peranan penting pada return investor. Oleh karena itu dapat disimpulkan bahwa harga saham masa lalu mempengaruhi harga saham masa sekarang yang mempunyai pola tertentu dan berulang sehingga berpengaruh secara psikologis terhadap investor dalam melakukan transaksi pedagangan. Menurut Sunariyah (1997) ada beberapa teknik analisis yang dapat digunakan dalam pendekatan teknikal antara lain trend analisis yang mengasumsikan bahwa perilaku harga saham masa lalu merefleksikan harga saham dimasa yang akan datang. Para analis teknikal cenderung berkonsentrasi pada jangka pendek karena teknik analisis teknikal dirancang untuk mendeteksi pergerakan harga dalam jangka waktu yang relatif pendek. Jadi jika harga saham lebih dipengaruhi harga saham masa lalu berarti investor cenderung menyukai investasi jangka pendek untuk mendapat capital gain atau tidak menahan sahamnya dalam waktu lama untuk mendapat deviden.

Nilai koefisien regresi harga saham masa lalu dua tahun sebelumnya (P2) sebesar 0,066, artinya P2 mempunyai pengaruh positif terhadap harga saham, tetapi berdasarkan uji t variabel P2 tidak mempunyai pengaruh yang signifikan terhadap harga saham. Hal ini terjadi karena para investor cenderung menggunakan harga saham masa lalu satu tahun sebelumnya (P1) untuk melakukan analisis investasi, dan tidak menggunakan harga saham masa lalu dua tahun sebelumnya (P2). Oleh karena itu, harga saham masa lalu dua tahun sebelumnya tidak mempengaruhi perubahan harga saham atau dengan kata lain, harga saham masa lalu dua tahun sebelumnya tidak merefleksikan harga saham di masa yang akan datang.

\section{E. KESIMPULAN DAN REKOMENDASI}

Variabel kinerja keuangan yang diwakili oleh CAR, ROA, NIM, NPL, LDR, EPS, PER dan faktor teknikal yaitu harga saham masa lalu menunjukkan bahwa secara simultan (serentak) mempunyai pengaruh yang signifikan terhadap harga saham pada perusahaan perbankan pada tahun 2005. hal ini berarti perubahan CAR, ROA, NIM, NPL, LDR, EPS, PER, P1, P2 secara bersama-sama dapat digunakan sebagai variabel untuk memprediksi perubahan harga saham. Dengan demikian dengan menganalisis 9 variabel tersebut investor atau masyarakat dapat menentukan pilihan yang tepat untuk berinvestasi pada saham perusahaan yang menguntungkan.

Variabel kinerja keuangan yang secara parsial mempunyai pengaruh signifikan adalah EPS dan PER. Sedangkan untuk faktor teknikal yaitu harga saham masa lalu satu tahun sebelumnya. Dengan demikian, selain melakukan penilaian secara simultan, investor atau masyarakat yang akan melakukan penganalisaan atas kinerja keuangan tertentu yang secara individual berpengaruh signifikan terhadap harga saham. Dalam hal ini adalah EPS dan PER sehingga dapat menghasilkan keputusan yang lebih akurat dalam menentukan pilihan untuk berinvestasi pada perusahaan perbankan. Selain itu juga harus diperhatikan faktor teknikal yaitu harga saham masa lalu satu tahun sebelumnya.

Arah pengaruh variabel ROA dan NIM terhadap harga saham yang berkebalikan memberikan gambaran bahwa dengan melihat pada variabel ini, akan memberikan risiko yang lebih besar jika dibandingkan dengan variabel penelitian lain yang memiliki hubungan yang signifikan terhadap harga saham. Hal ini dikarenakan dengan adanya ROA yang besar hanya bersifat jangka pendek. Dan juga tingginya NIM menandakan bank tidak efisien karena besarnya biaya operasional. 
Journal of Indonesian Applied Economics

Vol. 4 No. 1 Mei 2010, 71-80

\section{DAFTAR PUSTAKA}

Fakhruddin, M \& Sopian, H, 2001, Perangkat dan Model Analisa Investasi di Pasar Modal, PT Elex Media Komputindo Gramedia, Jakarta.

Husnan,Suad, 2003, Dasar-dasar Teori Portofolio dan Analisis Sekuritas, edisi Ketiga, UPP AMP YKPN, Yogyakarta.

Jogiyanto, Hartono, 1998, Teori Portofolio dan Analisis Investasi, Edisi Pertama, BPFE Yogyakarta, Yogyakarta.

Purnomo, 1998, Keterkaitan Kinerja Keuangan dengan Harga Saham, Managemen Usahawan Indonesia, Vol.27, No.12. Desember.

Setiawati, Dwi, 2006, Investor Asing Tergila-Gila Saham Di Bursa, Info Bank, Vol.28, No. 322. Januari.

Setiawati, Dwi, 2006, Peruntungan Fluktuasi Saham Bank Swasta, Info Bank, Vol.28, No. 325. April.

Suad, Husnan, 1996, Dasar-dasar Teori Portofolio dan Analisis Sekuritas, edisi Kedua, UPP AMP YKPN, Yogyakarta.

Sukirno, Sadono, 2000, Pengantar Teori Mikro Ekonomi, Rajawali Pers, Jakarta.

Sunariyah, 1997, Pengantar Pengetahuan Pasar Modal, Cetakan Pertama, UPP AMP YKPN, Yogyakarta.

Tandelilin, E, 2004, Analisa Investasi Dan Manajemen Portofolio, Edisi Pertama, BPFE, Yogyakarta.

aufik, 2001, Kajian Capital Market, Leverage dan Profitability Terhadap Harga Saham Di Bursa Efek Jakarta, Jurnal Kajian Ekonomi dan Bisnis, Vol.3, No.2, Agustus.

Tjiptono, Darmadji dan Hendy, Fakhruddin, 2001, Pasar Modal Indonesia: Pendekatan Tanya Jawab, Salemba Empat, Jakarta.

Weston, J.F., \& Copeland, T.E., 1997, Manajemen Keuangan, Terjemahan Oleh Jaka Wasana \& Kibrandoko, Edisi Kesembilan Jilid I, Binarupa Aksara, Jakarta. 